\title{
The Effectiveness of Psychoreligius Therapy on Sleep Quality and Anxiety in Diabetes Mellitus Patientstype 2
}

\author{
Fendy Valentino Fauzan Aftina ${ }^{1}$, Sri Poeranto ${ }^{2}$, Yulian Wiji Utami ${ }^{3}$ \\ ${ }^{1}$ Master of Nursing Program, Faculty of Medicine, Brawijaya University, Indonesia \\ ${ }^{2}$ Medical Program, Faculty of Medicine, Brawijaya University, Indonesia \\ ${ }^{3}$ Nursing Program, Faculty of Medicine, Brawijaya University, Indonesia \\ Email: fendyfauzan92@gmail.com
}

\begin{abstract}
Diabetes mellitus is a chronic degenerative disease characterized by an increase in glucose levels in the blood. Anxiety and sleep quality disturbances are problems that are often experienced by people with diabetes mellitus due to prolonged stressors. The purpose of this study was to determine the effectiveness of psychoreligious therapy on anxiety scores and sleep quality scores in type 2 diabetes mellitus patients in the Junrejo Health Center, Batu City. This study used a queasy experimental design with a pretest and posttest control group design. The number of samples was 36 respondents who were divided into the experimental group (psychoreligious therapy) and the control group (health education) each of 18 respondents. The sample selection used purposive sampling. The results of this study indicate that psychoreligious therapy has $\rho$ value $<0.05$, which means that there is a significant difference between the difference in anxiety scores and the difference in sleep quality scores before and after being given psychoreligious therapy, so the alternative hypothesis is accepted and the null hypothesis is rejected. This study concludes that psychoreligious therapy is more effective than health education on anxiety and sleep quality in patients with type 2 diabetes mellitus.
\end{abstract}

Keywords: Psychoreligious, Type 2 Diabetes Mellitus, Anxiety, Sleep Quality.

\section{A. INTRODUCTION}

Diabetes mellitus is a chronic degenerative disease characterized by an increase in blood glucose levels or hyperglycemia that exceeds normal limits (ADA, 2017). A person with diabetes mellitus is very at risk of health complications and reduced overall quality of life so that individuals who experience this chronic disease need special attention from all elements of society, especially health workers (Khalighi et al., 2019).

The most common diabetes mellitus is type 2 diabetes mellitus, amounting to $8.5 \%$ worldwide (Alenazi et al., 2019). The prevalence of diabetes mellitus worldwide has increased every year. In 2018, more than 500 million individuals living with type 2 diabetes mellitus (Kaiser et al, 2018). It is estimated that nearly 600 million people worldwide in 2035 will suffer from type 2 diabetes mellitus. Overall, type 2 diabetes dominates around 90-95\%. The International Diabetes Federation (IDF) (2011) estimates that in 2010 there are 287 million adults with diabetes mellitus in seven regions of the world and by 2030 this figure will continue to increase to 439 million people (Murdiono, 2011). In Indonesia, the prevalence of diabetes mellitus in people aged over 15 years has increased from 2013-2018. In 2013 the number of 
people experiencing DM was $1.5 \%$ and in 2018 it was $2.0 \%$. It is estimated that the number of sufferers of diabetes mellitus in East Java is 1.9\% in 2013 and $2.4 \%$ in 2018 (RISKESDAS, 2018).

Diabetes mellitus has manifestations in the form of a loss of carbohydrate tolerance resulting in symptoms of polydipsia (thirst), polyuria (increased urine output), polyphagia (increased hunger), and blurred vision (Price and Wilson, 2014). These clinical symptoms can interfere with sleep, resulting in increased frequency of awakening, difficulty falling asleep again, sleep dissatisfaction, resulting in decreased sleep quality (Gustimigo, 2015). Besides, anxiety is a problem often experienced by people with diabetes mellitus due to prolonged stressors (Khalighi et al., 2019).

Therapy for diabetes mellitus sufferers who experience anxiety and sleep quality disturbances should be carried out holistically (thoroughly) which includes biological, psychological, social, and spiritual (Yosep \& Sutini, 2016). Management can be in the form of pharmacological, non-pharmacological, and several therapeutic modalities. In this study, researchers used a therapeutic modality, namely psychoreligious therapy.

Researchers use this therapy because the level of individual healing is influenced by the level of religiosity, where the more religious a person is, the easier the healing process will be. Is as stated by Yosep \& Sutini (2016) that religiosity can prevent and protect individuals from mental disorders, reduce suffering, and increase the healing process.

Based on the description above, researchers are interested in researching the effectiveness of psychoreligious therapy to overcome anxiety problems and sleep quality in patients with type 2 diabetes mellitus. Community needs for religion are a priority. Through this discipline, it is hoped that his need for inner calm in the conditions of life problems experienced can have a positive influence on the patient's psychological condition.

\section{B. METHOD}

This study used a queasy experimental design with a pretest and posttest control group design. The number of samples was 36 respondents divided into an experimental group (psychoreligious therapy) and a control group (health education) with 18 respondents each. The sample selection in this study using purposive sampling. The inclusion criteria in this study were type 2 diabetes mellitus sufferers who are experiencing anxiety and sleep quality disturbances, aged 30-50 years, Muslim, people with type 2 diabetes mellitus who are willing to become research respondents by signing the informed consent and have not received other interventions. The exclusion criteria of this study were people with type 2 diabetes mellitus with complications (it is known from the data obtained from Junrejo Health Center, Batu City). This research was conducted on 20 September - 20 October 2020 at the Junrejo Health Center, Batu City, Indonesia. 
The instruments used in this study were the Hamilton for anxiety Rating Scale (HARS) questionnaire to measure anxiety scores and the Pittsburgh Sleep Quality Index (PSQI) to measure sleep quality scores. Bivariate analysis was analyzed using a paired T-test, Wilcoxon test, and Mann-Whitney test.

\section{RESULT AND DISCUSSION}

Anxiety scores before and after given Psychoreligious Therapy in the treatment group can be seen in table 1 below:

Table 1. Anxiety Scores Before and After Being Given Psychoreligious Therapy in the Treatment Group

\begin{tabular}{lcc}
\hline \multicolumn{1}{c}{ Respondent Characteristics } & Frequency & Percentage \\
\hline Profession & 9 & \\
\hline Traders & 8 & $25 \%$ \\
Farmer & 3 & $22,2 \%$ \\
Civil Servants & 4 & $8,3 \%$ \\
Businessman & 12 & $11,1 \%$ \\
Does not Work & 36 & $33,3 \%$ \\
\hline Total & & $\mathbf{1 0 0 , 0} \%$ \\
\hline Education Level & 4 & \\
\hline College & 13 & $11,1 \%$ \\
Primary School & 7 & $36,2 \%$ \\
Senior High School & 9 & $19,4 \%$ \\
Junior High School & 3 & $25 \%$ \\
No School & 36 & $8,3 \%$ \\
\hline Total & & $\mathbf{1 0 0 , 0} \%$ \\
\hline Gender & 15 & \\
\hline Male & 21 & $41,7 \%$ \\
Female & 36 & $58,3 \%$ \\
\hline Total & & $\mathbf{1 0 0 , 0} \%$ \\
\hline Age & 10 & \\
\hline 30-35 Years & 7 & $\mathbf{1 0 0 , 0} \%$ \\
36-40 Years & 13 & $19,4 \%$ \\
$41-45$ Years & 6 & $16,7 \%$ \\
46-50 Years & 36 & \\
\hline Total & 36 & \\
\hline
\end{tabular}

Table 1 shows that the largest number of respondents were female, as many as 21 people $(58.3 \%)$. Based on the age characteristics, most respondents with a percentage of $36.1 \%$ (13 people) were the $41-45$ years age group. Based on the educational characteristics, $36.1 \%$ (13 people) with elementary education level, and $33.3 \%$ (12 people) did not work. 
Table 2. Anxiety Scores Before and After Given Psychoreligious Therapy in the Treatment Group

\begin{tabular}{lrrrrr}
\hline Paired T-Test & Mean & SD & $d f$ & $t$ & Sig (2-tailed) \\
\hline $\begin{array}{l}\text { Anxiety Before } \\
\begin{array}{l}\text { Treatment-Anxiety } \\
\text { After Treatment }\end{array}\end{array}$ & 16,444 & 4,961 & 17 & 14,062 & 0,000 \\
\hline
\end{tabular}

Based on the Statistical Test in Table 2, it is known that Asymp. Sig (2-tailed) of $0.000<0.05$ then $\mathrm{H} 0$ is rejected, so there is a significant effect of anxiety between before and after being given psychoreligious therapy in the treatment group.

Table 3. Anxiety Scores Before and After Given Psychoreligious Therapy in the Treatment Group

Paired T-Test

\begin{tabular}{|c|c|c|c|c|c|}
\hline & Mean & SD & $D f$ & $T$ & Sig (2-tailed) \\
\hline Before Exit & & & & & \\
\hline $\begin{array}{l}\text { Control - Anxiety After } \\
\text { Exit Control }\end{array}$ & 2,444 & 2,854 & 17 & 3,634 & 0,002 \\
\hline
\end{tabular}

Based on the Statistical Test in Table 3, it is known that Asymp. Sig (2-tailed) of $0.005<0.05$, then $\mathrm{H} 0$ is rejected, so there is a significant effect of anxiety between before and after being given health education in the control group.

Table 4. Wilcoxon Test of Sleep Quality Score Before and After Being Given Psychoreligious Therapy in the Treatment Group

\begin{tabular}{llcccc}
\hline Wilcoxon Signed Ranks Test & & & & \\
Sleep Quality & & $N$ & Mean Rank & $\begin{array}{c}\text { Sum of } \\
\text { Rank }\end{array}$ & $\begin{array}{c}\text { Asymp. Sig (2- } \\
\text { tailed) }\end{array}$ \\
\hline $\begin{array}{l}\text { Sleep Quality } \\
\text { Before and After }\end{array}$ & Negative Ranks & 18 & 9,50 & 171,00 & \\
the Treatment & Ties & 0 & 0,00 & 0,00 & 0,000 \\
Group & Total & 18 & & & \\
\hline
\end{tabular}

Based on the Statistical Test in table 4, the Wilcoxon Signed Ranks Test, it is known that Asymp. Sig (2-tailed) of $0.000<0.05$, then H0 is rejected, so there is a significant effect on sleep quality between before and after being given psychoreligious therapy in the treatment group.

Table 5. Paired T-Test Sleep Quality Score Before and After Health Education in the Control Group

\begin{tabular}{lrrrrrc}
\hline Paired T-Test & \multicolumn{1}{c}{ Mean } & SD & df & T & Sig (2-tailed) \\
\hline Sleep Quality & Before & Exit & & & & \\
$\begin{array}{l}\text { Control - Sleep } \\
\text { Exit Control }\end{array}$ & Quality After & 2,222 & 2,557 & 17 & 2,650 & 0,017 \\
\hline
\end{tabular}


Based on the Statistical Test in Table 5, it is known that Asymp. Sig (2-tailed) of $0.017<0.05$, then $\mathrm{H} 0$ is rejected, so there is a significant effect on the sleep quality score between before and after being given health education in the control group.

Table 6. Bivariate Analysis Result

\begin{tabular}{llllll}
\hline Mann-Whitney Test & & & & & \\
\hline & Group & $N$ & $\begin{array}{l}\text { Mean } \\
\text { Rank }\end{array}$ & $\begin{array}{l}\text { Sum of } \\
\text { Ranks }\end{array}$ & $\begin{array}{l}\text { Sig(2- } \\
\text { tailed) }\end{array}$ \\
\hline $\begin{array}{llllll}\text { Difference in Anxiety } \\
\text { Score Before and After }\end{array}$ & Treatment & 18 & 10,58 & 190,50 & 0,000 \\
\cline { 2 - 6 } & Control & 18 & 26,42 & 475,50 & \\
\hline
\end{tabular}

Based on the Statistical Test in table 6, it is known that Asymp. Sig (2-tailed) of $0.000<0.05$, then $\mathrm{H} 0$ is rejected, so there is a significant difference in the difference in anxiety scores before and after being given psychoreligious therapy.

Table 7. Bivariate Analysis Result

Mann-Whitney Test

\begin{tabular}{|c|c|c|c|c|c|}
\hline & Group & $N$ & $\begin{array}{l}\text { Mean } \\
\text { Rank }\end{array}$ & $\begin{array}{l}\text { Sum of } \\
\text { Ranks }\end{array}$ & $\begin{array}{l}\text { Sig (2- } \\
\text { tailed) }\end{array}$ \\
\hline difference & Treatment & 18 & 11,78 & 212,00 & \multirow[b]{2}{*}{0,000} \\
\hline $\begin{array}{l}\text { Quality Score Before and } \\
\text { After }\end{array}$ & Control & 18 & 25,22 & 454,00 & \\
\hline
\end{tabular}

Based on the Statistical Test in table 7, it is known that Asymp. Sig (2-tailed) of $0.000<0.05$, then $\mathrm{H} 0$ is rejected, so there is a significant difference in the difference in sleep quality scores before and after being given psychoreligious therapy.

From the results obtained, the data shows that the majority of DM sufferers are female, namely 21 respondents compared to DM patients who are male, namely 15 respondents. These results are the same as the research conducted by Tentero, Damayanti, Pangemanan, Polii in 2016 with the title of the study of the Relationship of Diabetes Mellitus with Sleep Quality, namely that most DM patients are female, 50 people (male 28 people).

The results of this study indicate that the average age who experiences type 2 diabetes is 41-45 years. Damayanti (2015) explains that the risk factor for developing type 2 diabetes is over 30 years of age, this is due to an anatomical, physiological, and biochemical decline. This is supported by research conducted by Mahmuda, Thohirun, Prasetyowati (2016) who explained that most of the type 2 diabetes mellitus occurred at the age of more than 40 years with a total of 60 respondents from the 65 respondents studied.

Based on the results of research conducted in the Junrejo Health Center, Batu City, from 36 respondents, it was found that 13 respondents $(36.1 \%)$ had the highest education level. Low levels of education have a higher incidence of diabetes mellitus than those with high education. As well as a low socioeconomic status which will affect poor health maintenance and have an impact on the increased risk of diabetes (Allorerung, 2016). 
The majority of respondents' job status was not working, namely 12 respondents $(33.3 \%)$. Most respondents are the unemployed group and are also female. This group is housewives (IRT). The results of this study are in line with research conducted by Zainuddin et al. (2015) which showed that the majority of diabetic patients were IRTs with a presentation of $46.7 \%$. Besides, the results of research conducted by Tarihoran, Muttaqin, \& Mulyani (2015) explained that most of the occupations of type 2 diabetes mellitus patients were IRT with 18 respondents out of 30 respondents.

The results of this study indicate that there is a significant difference between the average anxiety scores before and after the intervention in the treatment group. Researchers assume that the difference in anxiety scores in the treatment group can occur due to psychoreligious therapy (prayer, dhikr, and sholat). Dhikr causes a very relaxed state so that the body's metabolism decreases, the heart rate slows down, blood pressure decreases, and the breath becomes calmer and more regular (Zamri, 2012).

The results of this study indicate that the psychoreligious therapeutic intervention of prayer, remembrance, and prayer can reduce the anxiety score of type 2 DM sufferers tranquility, to avoid stress, anxiety, fear, and anxiety. Individuals who suffer from type 2 diabetes mellitus need support, direction, health education to increase independence.

The description above explains that remembrance therapy, trusting in Allah, and spiritual activities are carried out to get a cure for illness. Besides, dhikr therapy can reduce anxiety, because doing dhikr with confidence can revive the heart, provide peace, peace of mind so that it can increase immunity. A person who is religious or obedient in carrying out his religious teachings is relatively healthier and able to overcome his illness so that the healing process is faster. In principle, in the human body, there is a psychoneuroendocrine network that influences a person's psychological factors. This network affects the immune system. Recitation which is used as apsychoreligious therapy will be able to increase human immunity through the psychoneuroendocrine network.

Psychoreligious needs are the need to maintain or restore faith and fulfill religious obligations, as well as the need to get forgiveness or forgiveness, to love, to have a trusting relationship with God with a spiritual or religious approach (Asmaroh et al., 2020). According to researchers, the decrease in the average score of anxiety in the intervention group can occur due to psychoreligious therapy, namely by praying, remembrance, and prayer because of relaxation so that the parasympathetic nervous system stimulates the decrease in all functions raised by the sympathetic nervous system so that it can suppress tension and anxiety.

This psychoreligious therapy is a non-invasive nursing action that does not cause injury or side effects. Psychoreligious therapy intervention is very appropriate to be applied to type $2 \mathrm{DM}$ sufferers who experience anxiety because the problems of type $2 \mathrm{DM}$ clients are not only physical aspects but psychological aspects can also occur. The psychological problem that often occurs is anxiety. Anxiety is one of the 
nursing diagnoses of type $2 \mathrm{DM}$ clients that must be addressed immediately because excessive anxiety can suppress endorphin hormones and increase the hormone cortisol so that it can suppress immunity. In dealing with client's fears and worries, spiritual belief has an important role. Spiritual is one of the elements of complete health apart from bio-psycho-social elements. Prayer, dhikr, and prayer are spiritual/spiritual nutrients so that with the application of this psychoreligious therapy the client's needs can be fulfilled inwardly.

The results of this study are also in line with research conducted by Hastuti et al. (2019) that reciting dhikr can improve sleep quality. The effect of reciting dhikr stimulates the hypothalamus to influence the pineal gland to improve immune function and produce melatonin. The optimal secretion of melatonin is mediated by the relaxation response that results from reciting the dhikr. In this condition, the organs, cells, and all substances in the body move to function in a balanced state, resulting in a feeling of calm in the body (Putra, 2013).

This improvement in sleep quality is due to an increase in the work of the sympathetic nerves. This is in line with research by Al-Halaj (2014) which can stimulate the parasympathetic nervous system which has an opposite effect to the sympathetic nervous system, causing a balance between the two autonomic nerves. This is the basic principle of the relaxation response, namely the balance between the sympathetic nervous system and the parasympathetic nervous system.

From the data above, the researcher can conclude that psychoreligious therapy can overcome sleep pattern disorders, as evidenced by the amount of good sleep quality in respondents has increased and the mean value has decreased, which means that the value of the Pittsburg Sleep Quality Index (PSQI) is low. The quality of the respondents' sleep became good after being given the intervention because the elderly felt calmer, more comfortable, did not feel alone, we're not afraid in any condition and situation and the level of worship had increased. In addition to sleep patterns, psychoreligious therapy can also reduce anxiety and overcome depression in people with type 2 diabetes mellitus, which triggers sleep disorders.

A sense of calm will generate positive emotions that will be transmitted to the limbic system and cerebral cortex with a complex level of connectivity between the hypothalamus-prefrontal brainstem left and right hippocampus-amygdala. This transmission causes a balance between the synthesis and secretion of neurotransmitters such as GABA (Gamma Amino Butyric Acid) and GABA antagonists by the hippocampus and amygdala. Dopamine, serotonin, and norepinephrine are produced by the prefrontal. Acetylcholine, endorphins (a natural calming effect in the body) by the hypothalamus. ACTH (Adrenocortico Releasing Hormone) is also balanced so that it affects the balance of the adrenal cortex in secreting cortisol, normal cortisol levels can act as a stimulator to the immune response of the body, both specific and nonspecific. A calm mental state can create a balance in the body that can increase immunity and can improve sleep quality (Wulandari \& Nashori, 2014). 


\section{E. CONCLUSION}

Psychoreligious therapy is effective in type 2 diabetes mellitus patients who experience anxiety and sleep quality disturbances. It is suggested that psychoreligious therapy can be used as an option in overcoming anxiety problems and sleep quality disorders experienced by people with type 2 diabetes.

\section{REFERENCES}

1. Alenazi, A. M., Alothman, S., Alshehri, M. M., Rucker, J., Waitman, L. R., Wick, J., ... \& Kluding, P. M. (2019). The prevalence of type 2 diabetes and associated risk factors with generalized osteoarthritis: a retrospective study using ICD codes for clinical data repository system. Clinical Rheumatology, 38(12), 35393547.

2. Al-Halaj, Q. M. I. (2015). Pengaruh Dzikir Menjelang Tidur Terhadap Kualitas Tidur Lanjut Usia di Panti Sosial Tresna Wredha Budi Mulia 01 Jakarta Timur. Jakarta: UIN Syarif Hidayatullah.

3. American Diabetes Association. (2017). Standards of Medical Care in Diabetes 2017. Vol. 40. USA: ADA

4. Allorerung, D. L., Sekeon, S. A., \& Joseph, W. B. (2016). Hubungan antara umur, jenis kelamin dan tingkat pendidikan dengan kejadian diabetes melitus tipe 2 di puskesmas ranotana weru kota manado tahun 2016. Universitas Sam Ratulangi.

5. Asmaroh, U., Ekacahyaningtyas, M., \& Kartina, I. (2020). Pengaruh Pemberian Terapi Psikoreligius (Dzikir Tasbih) Terhadap Kualitas Tidur Lansia di RW 02 Jebres Wilayah Kerja UPT Puskesmas Sibela (Doctoral dissertation, Universitas Kusuma Husada Surakarta).

6. Damayanti, S. (2015). Diabetes Melitus $\mathcal{E}$ Penatalaksanaan Keperawatan. Yogyakarta: Nuha Medika.

7. Gustimigo, Z. P. (2015). Kualitas Tidur Penderita Diabetes Melitus. Lampung: Fakultas Kedokteran Universitas Lampung.

8. Hastuti, R. Y., Sari, D. P., \& Sari, S. A. (2019). Pengaruh Melafalkan Dzikir terhadap Kualitas Tidur Lansia. Jurnal Keperawatan Jiwa, 7(3), 303-310.

9. International Diabetes Federation. (2011). IDF Diabetes Atlas Seventh Edition 2011. World: IDF.

10. Kaiser, A. B., Zhang, N., \& Van Der Pluijm, W. (2018). Global prevalence of type 2 diabetes over the next ten years (2018-2028).

11. Khalighi, Z., Badfar, G., Mahmoudi, L., Soleymani, A., Azami, M., \& Shohani, M. (2019). The prevalence of depression and anxiety in Iranian patients with diabetes mellitus: A systematic review and meta-analysis. Diabetes $\mathcal{E}$ Metabolic Syndrome: Clinical Research E Reviews, 13(4), 2785-2794.

12. Mahmuda, N. L. (2016). Faktor yang Berhubungandengan Tingkat Kecemasan Penderita Diabetes Melitus Tipe 2 di Rumah Sakit Nusantara Medika Utama. Jurnal Kesehatan, 8(2). 
13. Murdiono, W. R. (2011). Pengaruh Tindakan Keperawatan Generalis Harga Diri Rendahdan Terapi Kelompok Suportif Terhadap Harga Diripada Klien DM di RS Panembahan Senopati Bantul. Jakarta: FIK UI.

14. Price, S. A., \& Wilson, L. M. (2014). Patofisiologi: Konsep Klinis Proses-Proses Penyakit. Jakarta: EGC.

15. Putra, A. D. D. (2013). Kombinasi Eszopiclone dan Mind-Body Therapy sebagai Strategi Baru dalam Penatalaksanaan Insomnia. Denpasar: Universitas Udayana.

16. Riset Kesehatan Dasar (Riskesdas). (2018). Badan Penelitian dan Pengembangan Kesehatan Kementerian RI tahun 2018. Retrieved from http://www.depkes.go.id/resources/download/infoterkini/materi rakorpop 201 8/Hasil\%20Riskesdas\%202018.pdf.

17. Tarihoran, A., Muttaqin, A., \& Mulyani, Y. (2015). The Relationship Between Sleep Quality With Blood Sugar Levels of Patients of Diabetes Mellitus Type 2. Caring, 1(2).

18. Tentero, I. N., Pangemanan, D. H., \& Polii, H. (2016). Hubungan diabetes melitus dengan kualitas tidur. eBiomedik, 4(2).

19. Yosep, I., \& Sutini, T. (2016). Buku Ajar Keperawatan Jiwa. Bandung: Refika Aditama.

20. Wulandari, E., \& Nashori, H. F. (2014). Pengaruh terapi zikir terhadap kesejahteraan psikologis pada lansia. JIP (Jurnal Intervensi Psikologi), 6(2), 235250 .

21. Zainuddin, M., Utomo, W., \& Herlina. (2015). Hubungan stres dengan kualitas hidup penderita diabetes mellitus tipe 2. JOM, 2(1), 890-898.

22. Zamri, A. M. (2012). Sehat Tanpa Obat: Cara Islam Meraih Kesehatan Jasmani dan Rohani (Terapi Spiritual Tarekat Al-Hikmah untuk Mengatasi Problem Kesehatan). Bandung: Marja. 